\title{
ON SOME INTEGRAL INEQUALITIES OF OPIAL TYPE
}

\author{
BRONISŁAW FLORKIEWICZ
}

Abstract. Integral inequalities of the form

$$
\int_{I} s|h|^{p}\left|h^{\prime}\right| d t \leqslant \int_{I} r\left|h^{\prime}\right|^{p+1} d t, \quad h \in H,
$$

are derived, where $p>0, I=(\alpha, \beta),-\infty \leqslant \alpha<\beta \leqslant \infty, r$ and $s$ are given real functions of the variable $t, H$ is the class of functions $h$, which are absolutely continuous on $I$ and satisfy the integral condition $\int_{I} r\left|h^{\prime}\right|^{p+1} d t<\infty$, as well as one of the following boundary conditions: $h(\alpha)=0$ or $h(\beta)=0$.

Mathematics subject classification (1991): 26D10.

Key words and phrases: absolutely continuous function, integral inequality, Opial inequality.

\section{REFERENCES}

[1] R. P. AGARWAL, Sharp Opial-type inequalities involving r-derivatives and their applications, Tôhoku Math. J. 47(1995), 567-593.

[2] R. P. Agarwal and P. Y. H. PANG, Opial Inequalities with Applications in Differential and Difference Equations, Kluwer, Dordrecht, 1995.

[3] R. P. Agarwal and P. Y. H. PANG, Remarks on the generalizations of Opial's inequality, J. Math. Anal. Appl. 190 (1995), 559-577.

[4] P. R. BEeSACK, Integral inequalities of Z. Opial, Trans. Amer. Math. Soc. 104 (1962), 470-475.

[5] P. R. Beesack, Integral inequalities involving a function and its derivative, Amer. Math. Monthly 78 (1971), 705-741.

[6] P. R. BEeSACK AND K. M. DAS, Extensions of Opial's inequality, Pacific J. Math. 26 (1968), 215-232.

[7] S. BLoom, First and second order Opial inequalities, Studia Math. 126 (1997), 27-50.

[8] D. W. BoYD, Best constants in a class of integral inequalities, Pacific J. Math. 30 (1969), 367-383.

[9] D. W. Boyd AND J. S. W. Wong, An extension of Opial's inequality, J. Math. Anal. Appl. 19 (1967), $100-102$.

[10] J. CALVERT, Some generalizations of Opial's inequality, Proc. Amer. Math. Soc. 18 (1967), 72-75.

[11] B. FlorkIEWICZ, Some integral inequalities of Hardy type, Colloq. Math. 43 (1980), 321-330.

[12] B. FloRKIEWICZ AND M. KUCHTA, Some quadratic integral inequalities the first order, Colloq. Math. 75 (1998), 7-18.

[13] B. FlorkiEWICZ AND A. RYBARSKI, Some integral inequalities of Sturm-Liouville type, Colloq. Math. 36 (1976), 127-141.

[14] M. KuchtA, Some quadratic integral inequalities of Opial type, Ann. Polon. Math. 63 (1996), 103-113.

[15] J.-D. LI, Opial-type integral inequalities involving several higher order derivatives, J. Math. Anal. Appl. 167 (1992), 98-110.

[16] D. S. Mitrinović, J. E. PeČARIĆ AND A. M. FinK, Inequalities Involving Functions and Their Integrals and Derivatives, Kluwer, Dordrecht, 1991, pp. 114-142.

[17] Z. Opial, Sur uné inegalité, Ann. Polon. Math. 8 (1960), 29-32.

[18] B. G. PACHPATTE, On Opial type inequalities involving higher order derivatives, J. Math. Anal. Appl. 190 (1995), 763-773. 
[19] D. T. SHUM, A general and sharpened form of Opial's inequality, Canad. Math. Bull. 17 (1974), 385-389.

[20] D. T. SHum, On a class of new inequalities, Trans. Amer. Math. Soc. 204 (1975), 299-341.

[21] G. J. Sinnamon, Weighted Hardy and Opial-type inequalities, J. Math. Anal. Appl. 160 (1991).

[22] J. S. W. WONG, A discrete analogue of Opial's inequality, Canad. Math. Bull. 10, 115-118.

[23] G. S. YANG, On a certain result of Z. Opial, Proc. Japan Acad. 42 (1966), 78-83. 